\title{
PEMETAAN TREN BELAJAR AGAMA MELALUI MEDIA SOSIAL
}

\author{
Suci Ramadhanti Febriani ${ }^{1}$, Ayu Desrani ${ }^{2}$ \\ ${ }^{1}$ UIN Maulana Malik Ibrahim Malang, Indonesia \\ ${ }^{2}$ STAI Sabili Bandung, Indonesia \\ ${ }^{1}$ suciramadhantifebriani11@gmail.com; ${ }^{2}$ aydesrani@gmail.com
}

Diterima: 8 Juli 2021 | Disetujui: 18 Juli 2021 | Dipublikasikan : 19 Juli 2021

\begin{abstract}
Abstrak
Pembelajaran agama menjadi salah satu prinsip kehidupan yang tidak terlepas dari aktivitas manusia. Pada umumnya pembelajaran agama memiliki berbagai strategi untuk mendalami ajarannya. Penelitian ini bertujuan untuk mengeksplorasi pemetaan tren pembelajaran agama melalui media sosial. Penelitian ini menggunakan desain penelitian kualitatif deskriptif pada responden yang berusia 19-25 tahun. Responden berjumlah 39 orang untuk mendapatkan informasi pemetaan tren pembelajaran agama masa kini dengan teknik analisis data menggunakan teknik analisis berbasis triangulasi data. Hasil penelitian menunjukkan bahwa tren belajar agama melalui media sosial tersebar pada penggunaan media yang bervariasi yaitu; 87,2\% menggunakan YouTube, 30,8\% menggunakan instagram dan artikel online, 15,4\% menggunakan facebook, selebihnya menggunakan media yang lainnya seperti WhatsApp dan Tiktok. Berdasarkan temuan, maka tren belajar agama telah beralih dari sistem tradisional pada sistem digital. Hal itu menunjukkan bahwa peran media sosial sangat mempengaruhi konsep berpikir dan bertindak dalam memperdalam pembelajaran agama. Atas dasar itu, penelitian ini merekomendasikan penelitian lanjutan bagi para pemangku kebijakan di Pendidikan Islam Kementerian agama maupun pada masyarakat umum untuk menguji efektivitas media sosial sebagai media belajar agama.
\end{abstract}

Kata Kunci: Belajar Agama, Media Sosial, YouTube

\section{Abstract}

Learning about religion, is one of the principles of life that is unseparable from human activities. In general, learning about religion has various strategies in its teachings. This study aims to explore the mapping of trends in learning about religion through social media. This study uses descriptive qualitative research by distributing instruments to 39 respondents aged 19-25 years to get information about current trends on learning about religion. The data is analyzed by data triangulation-based analysis techniques. The results show that the trending of learning about religion through social media is spread over the use of various media; $87.2 \%$ of respondents uses YouTube, 30.8\% uses Instagram and online articles, $15.4 \%$ uses Facebook, the others use other media such as WhatsApp and Tiktok. Based on the findings, the trending of religious learning shifts from traditional systems to digital systems. This shows that the role of social media greatly influences the concept of thinking and acting in deepening religious learning. On that basis, this study recommends further research for policy makers in the Ministry of Religion of Islamic Education and the general public to test the effectiveness of social media as a medium for learning about religion.

Keywords: Religious Learning, Sosial Media, YouTube

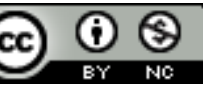




\section{PENDAHULUAN}

Di era modern sekarang ini, perkembangan teknologi informasi melalui internet merupakan salah satu cara masyarakat memperoleh informasi. Peralihan sumber informasi dari media offline pada media online berkembang sangat pesat. Hal tersebut ditandai oleh akses media online yang tersebar di berbagai platform media sosial (Kurnia \& Fitriyani, 2018). Kemajuan ini semakin memudahkan manusia untuk terhubung satu sama lain tanpa terbatas ruang dan waktu. Berbagai informasi dan peristiwa yang terjadi di seluruh dunia dapat dengan cepat dikenali oleh manusia di benua lain. Era globalisasi yang ditandai dengan perkembangan teknologi komunikasi disebut juga era informasi (Nuryana, 2019).

Kemajuan teknologi yang kompleks pada abad ini merupakan perwujudan dari aktivitas intelektual manusia yang maju. Aktivitas intelektual manusia merangsang peningkatan pengetahuan sistem dan metode. Munculnya teknologi media sosial telah membuatnya lebih mungkin dari pada sebelumnya bagi orang-orang untuk terhubung di berbagai wilayah, demografi, dan pandangan dunia. Media sosial juga berperan penting untuk membangun komunikasi sosial oleh teknologi informasi modern antara teman, keluarga, dan orangorang (Islam, 2019). Semangat ini menyebabkan perkembangan pesat sistem iptek industri. Fleksibilitas dan luasnya interaksi yang diberikan oleh teknologi virtual ini (khususnya melalui media sosial) memberikan kemungkinan bagi demokrasi untuk menyerap informasi tanpa terkontrol dan dikendalikan oleh media arus utama (Nuri, 2017). Media sosial mewujudkan dirinya sebagai ruang publik yang dapat digunakan untuk berbagai kepentingan, salah satunya juga sebagai sarana pengajaran (Khosyatillah, 2018).

Perkembangan media sosial tumbuh pesat di abad 21. Hal tersebut ditandai oleh perkembangan teknologi informasi yang semakin canggih dengan berbagai pilihan platform yang ditawarkan (Abdullah et al., 2018). Awalnya, media sosial lahir berdasarkan kepercayaan, tetapi dari tahun 2000-an hingga tahuntahun berikutnya. Media sosial telah muncul mendapat sambutan hangat dari para pengguna internet, tidak hanya karena perkembangan internet, media sosial juga banyak menghasilkan dampak positif dan negatif (Ramadhan \& Destiana, 2019).

Adapun dampak positifnya bahwa media sosial dapat dijadikan sebagai alat untuk belajar dan bersosialisasi di dunia maya (Faisal, 2020). Sedangkan dampak negatifnya adalah kecenderungannya terhadap media sosial sehingga enggan untuk belajar dan menghabiskan waktu dengan sia-sia (Zazin \& Zaim, 2017). Media sosial dapat membuat kita untuk dapat bertukar informasi dan berinteraksi dengan teman-teman kita yang sama-sama menggunakan media sosial. Dalam penelitian Nasrullah (2015) disebutkan bahwa media sosial merupakan alat medium di internet, yang memungkinkan penggunanya untuk mampu untuk merepresentasikan dirinya maupun bekerjasama, berinteraksi, berkomunikasi dengan pengguna lain serta membentuk ikatan sosial secara virtual.

Penduduk Indonesia sendiri sangat melek terhadap media sosial. Sebuah data yang terdapat dalam laporan berjudul Digital 2021: The Latest Insights Into The State of Digital, dikatakan bahwa dari total 274,9 juta penduduk di Indonesia, 170 juta di antaranya telah menggunakan media sosial. Artinya, angkanya tembus sekitar $61,8 \%$. Generasi milenial yang umum disebut generasi $\mathrm{Y}$ serta generasi $\mathrm{Z}$ yang merupakan generasi yang sangat berkuasa terhadap penggunaan media sosial di Indonesia sebagian besar dari mereka kalangan muda dengan rentang usia 25-34 tahun (Kemp, 2021).

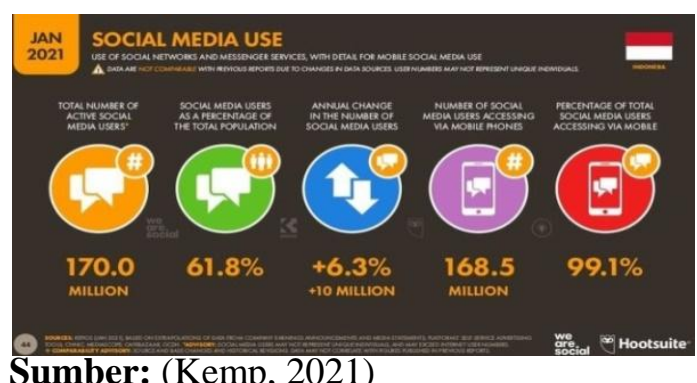

Gambar 1. Penetrasi Medsos di Indonesia 
Media sosial dimanfaatkan dengan berbagai macam fungsi salah satunya sebagai ladang informasi yang dapat menunjang kita dalam menimbah wawasan, seperti mempelajari ilmu agama dalam berbagai majelasi secara virtual atau secara langsung, sebagaimana firman Allah:

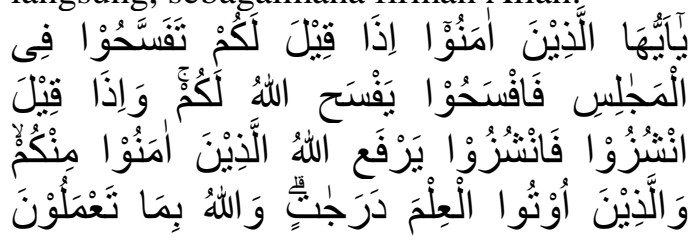

خَبْيْرُ (11)

Artinya: "Hai orang-orang beriman jika dikatakan atasmu: "Berlapang-lapanglah dalam majlis", maka lapangkanlah niscaya Allah akan memberi kelapangan untukmu. Dan jika dikatakan pula: "Berdirilah kamu", maka berdirilah, niscaya Allah akan mengangkat orang-orang yang beriman di antaramu dan orang-orang yang diberi ilmu pengetahuan beberapa derajat. Dan Allah Maha Mengetahui apa yang kamu kerjakan”. (QS. Al-Mujadalah: 11).

Sama halnya dengan hadits Rasulullah SAW :

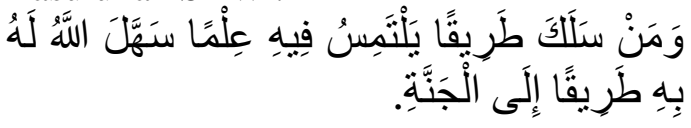

Artinya: "Siapa yang menempuh jalan untuk mencari ilmu, maka Allah akan mudahkan baginya jalan menuju surga." (HR. Muslim, no. 2699)

Dari ayat dan hadits di atas, sudah menjadi kewajiban bagi kita untuk belajar ilmu agama dan terus mencari informasi. Pada saat ini untuk mencari ilmu kita dibatasi oleh tempat dan waktu untuk belajar, apalagi di masa pandemi yang mana majelis-majelis tutup dan semua perkumpulan belajar ditiadakan. Media sosial dapat menjadi alternatif untuk menjalin silaturrahiim dan belajar mencari ilmu baik dalam suatu majelis, maupun melalui berbagai media yang ada. Dalam penelitian terbaru menyebutkan bahwa setengah dari anak muda atau sekitar 58\% dari mereka lebih suka belajar agama melalui media sosial seperti Facebook, Youtube, Twiter dan Instagram. Selain itu, ternyata anak-anak muda banyak yang tidak mengenal organisasi-organisasi keagamaan, dan mereka cenderung lebih mengenal pendakwah individual yang aktif di media sosial (Wibowo, 2019).

Dengan demikian, para penyebar dakwah Islam atau yang sering dikenal pendakwah akan dikenal dengan sangat cepat dikalngan masyarakat seperti: Gus Miftah, Ustadz Adi Hidayat, Gus Baha, Ustadz Abdul Shomad dan pendakwah lainnya. Mayoritas dari mereka mempunyai pengikut ribuan bahkan jutaan di media sosial masing-masing. Pemanfaatan platform-platform dari media sosial seperti; Twitter, Facebook, Instagram dan YouTube sangat memberikan dampak yang signifikan terhadap ketenaran atau kemasyhuran seorang tokoh pendakwah di media sosial (Hatta, 2018).

Era digital merupakan era dimana sumua akses dapat dijangkau dengan cepat oleh pengguna media sosial, akses yang begitu cepat tersebut dengan cepat akan viral atau menyebarluas. Hal inilah yang membuat para penyebar dakwah Islam atau pendakwah berupaya untuk melakukan pemanfaatan sosial media secara maksimal untuk menyampaikan dakwah mereka, yang mana penggunaan media sosial terbaru dan efektif dari pada media lainnya (Wibowo, 2019).

Menurut Fachrul Razi, Menteri Agama RI periode 2019-2020, mengatakan bahwa minat terhadap isu pemahaman agama di media sosial sangat tinggi. Data tersebut juga mencerminkan setengah dari keseluruhan masyarakat Indonesia menggunakan medsos untuk interaksi dan mencari informasi kehidupan, termasuk agama. "Terdapat 9,89 orang Indonesia menggunakan medsos untuk mencari dan menyebarkan informasi tentang agama," ujar Fachrul dalam Rapat Koordinasi Nasional Indonesia Maju di Sentul International Convention Center (Alika, 2019).

Ada berbagai cara yang dapat diterapkan oleh para pendakwah, mereka tidak hanya berdakwah secara tertulis dan berbicara saja, tapi juga dapat menggunakan vasilitas media audiovisual gambar, suara ataupun ceramah yang disesuaikan dengan perkembangan teknologi saat ini. Dengan konsep seperti 
ini dapat menaikkan jumlah followers (pengikut) mereka dari hari kehari semakin bertambah dan tersebar luas dari seluruh penjuru baik kalangan anak-anak, remaja sampai kalangan dewasa dan orang tua (Nuri, 2017).

Untuk mengembangkan, dan menyebarluaskan dakwah Islam pada masyarakat yaitu melalui unggahan video rekaman kajian Islam ke media sosial. Youtube dan media sosial lainnya yang berbasis video yang kini banyak dimanfaatkan oleh panitia kajian Islam, para pendakwah maupun individu jamaah untuk berbagi video ceramah atau dakwah Islam. Selain itu tidak sedikit pula panitia kajian keislaman yang menyediakan layanan live streaming via media sosial YouTube agar memudahkan masyarakat untuk turut serta dalam menikmati indahnya menuntut ilmu agama (Killian, 2014).

Pernyataan di atas didukung oleh penelitian lainnya yang mengatakan bahwa media pembelajaran agama Islam berbasis media sosial sangat efektif untuk digunakan, yang mana memang notabenenya media sosial sangat akrab dikalangan para pelajar, bahkan memang porsi dunia maya mereka terkadang lebih besar dari porsi dunia nyata mereka (Sofiuddin, 2018; Zazin \& Zaim, 2017). Adapula penelitian yang mengatakan media sosial terutama instagram memiliki pengaruh yang sangat besar dalam memperkenalkan dakwah Islam dan sarana komunikasi antara pendakwah jama'ah ini ditunjukkan dari nilai critical ratio yang jauh diatas nilai kritis (Yusnawati et al., 2021). Artinya apa untuk mempelajari agama baik dalam pembelajaran atau diluar pembelajaran media sosial sangat membantu semua kalangan untuk belajar dan mencari informasi seputar kesenjangan yang belum diketahui di kehdupan seharihari (Gumilar et.al, 2017).

Berpijak dari beberapa penelitian sebelumnya, maka penelitian ini bertujuan untuk mengeksplorasi pemetaan tren pembelajaran agama melalui media sosial, sehingga penelitian ini diharapkan dapat memberikan kontribusi bagi pemetaan belajar agama menggunakan media sosial di Indonesia. Atas dasar itu, penelitian ini mengungkapkan bagaimana tren belajar agama melalui media sosial baik dari segi efektivitas dan keakuratan sosial media itu sendiri serta bagaimana akses pemanfaatan konten yang sering diikuti di media sosial?.

\section{METODE PENELITIAN}

Penelitian ini menggunakan desain penelitian kualitatif deskriptif. Penelitian kualitatif berfungsi untuk melihat fenomena yang terjadi dalam realita sosial secara mendalam dan holistik (Moleong, 2007). Responden penelitian diambil secara acak dengan teknik random sampling pada mahasiswa yang memiliki rentang usia 1925 tahun. Proses pengambilan data melalui aplikasi google form. Responden berjumlah 39 orang yang tersebar pada gambar berikut.

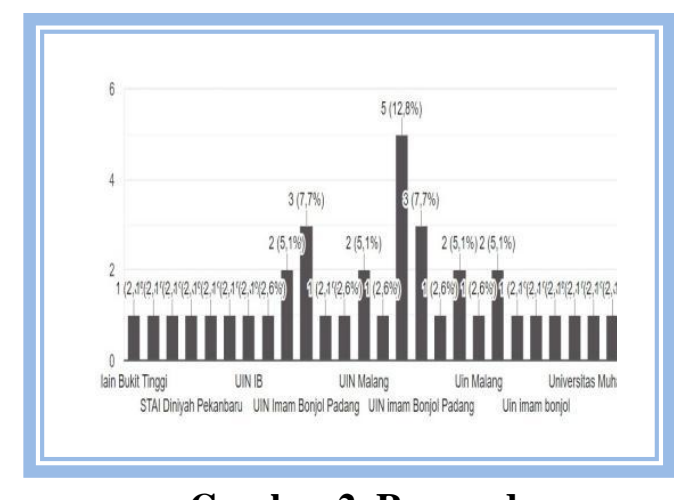

Gambar 2. Responden

Berdasarkan gambar 2, responden merupakan mahasiswa dari berbagai universitas untuk mengambil informasi terhadap penggunaan media sosial sebagai tren belajar agama.

Teknik pengumpulan data berdasarkan observasi virtual, dokumentasi serta penyebaran kuisioner terhadap tren pembelajaran agama melalui media sosial di Indonesia. Sebaran pertanyaan penelitian berjumlah 33 pertanyaan yang terdiri dari beberapa tema bahasan seperti strategi belajar agama, respon pembelajar serta media yang digunakan. Analisis penelitian menggunakan teknik triangulasi data berbasis teori Miles \& Huberman (1992) melalui tahapan pengumpulan data dengan menghitung respon butir pertanyaan serta telaah kritis terhadap argumentasi responden tentang pemetaan tren belajar agama melalui media sosial, mereduksi data 
primer, penyajian data serta pengambilan kesimpulan.

\section{TEMUAN DAN PEMBAHASAN}

\section{Temuan}

Pembelajaran agama dapat melalui berbagai sumber. Salah satu yang menjadi tren saat ini adalah pemanfaatan platform media sosial sebagai media dakwah di Indonesia. Sebaran media sosial yang bervariasi membentuk pola pikir masyarakat terutama pada generasi muda untuk beralih strategi pembelajaran agama pada sistem digital. Hal ini ditandai oleh sebaran data informan yang mengungkapkan hasil yang tertera pada gambar berikut.

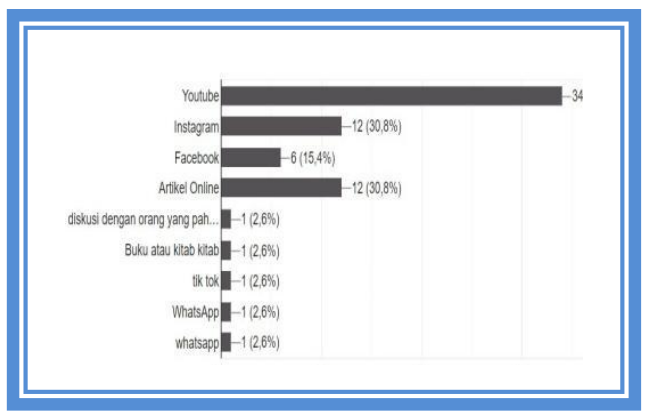

Gambar 3. Pemetaan Pembelajaran Agama

Berdasarkan gambar 3 bahwa sebaran responden terhadap belajar agama memiliki respon yang bervariasi. Hal teresut menunjukkan kecenderungan responden dalam belajar agama di media sosial terdiri dari beberapa kategori. Pertama, sebanyak $87,2 \%$ responden memanfaatkan platform YouTube untuk belajar agama. Kedua, sebanyak 30,8\% responden menggunakan Instagram dan artikel online. Ketiga, sebanyak $15,4 \%$ responden menggunakan Facebook. Kemudian selebihnya menggunakan buku dan media WhatsApp serta Tiktok.

Berdasarkan temuan tersebut, maka pemetaan pembelajaran agama di media sosial melalui YouTube. Melalui respon lainnya, peneliti menemukan berbagai alasan para responden memilih media tersebut. Akan tetapi, berbagai media visual, audio maupun audiovisual dapat tergambar pada gambar berikut.

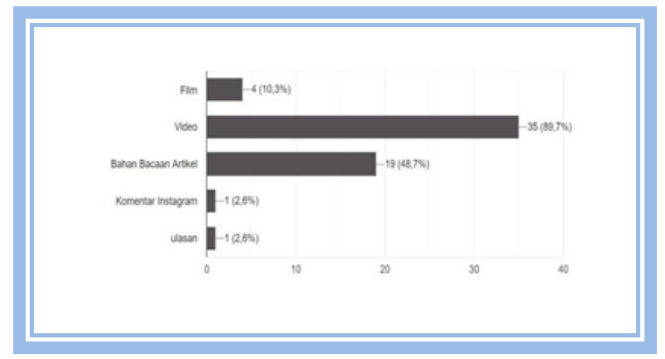

\section{Gambar 4. Media Pembelajaran}

Berdasarkan gambar 4, maka pemetaan pembelajaran agama berbasis media film sebanyak 10,3\%, sedangkan video sebanyak $89,7 \%$, sebanyak 48,7 menggunakan artikel dan hanya 2,6\% masing-masing menggunakan komentar instagram dan ulasan.

Melalui fenomena tersebut, maka pemetaan pembelajaran agama di era digital menjadi salah satu tren yang dapat dimanfaatkan para pengguna media sosial. Sebagaimana saat ini masyarakat selalu terintegrasi dengan media sosial sebagai alat komunikasi sehari-hari. Penyebaran data responden juga menunjukkan berbagai fenomena baru. Salah satunya pola pikkir masyarakat dapat dibentuk melalui media sosial ini. Hasil sebaran responden menunjukkan media sosial dapat mempengaruhi pemikiran dan pemahaman mereka. Sebagaimana bukti pada gambar berikut ini.

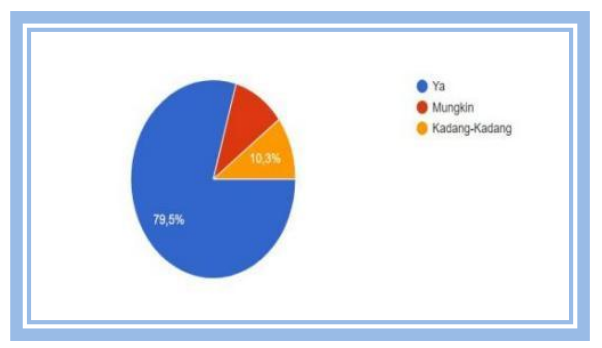

\section{Gambar 5. Tingkat Kevalidan Konten}

Berdasarkan gambar 5, maka pola pikir dan pemahaman serta pengetahuan para pengguna media sosial dapat dipengaruhi (79,5\%), sedangkan sebanyak 10,3\% masih cenderung kadang-kadang mempengaruhi pemikiran mereka dan kadang juga tidak. Selebihnya masih dalam kategori mungkin.

Melalui sebaran data menunjukkan alih kepercayaan masyarakat dapat dikonstruksi 
melalui konten media sosial. Akan tetapi, masih ada kekhawatiran terhadap konten yang disajikan dalam media sosial. Sebagaimana salah satu pernyataan responden mengungkapkan bahwa:

"Terkadang merasa sedikit khawatir apabila tidak diteliti dalam memilih video yang dilihat. Ya ketakutan akan video tersebut telah dirubah dari aslinya.. atau tidak lengkap sesuai aslinya apa yang dijelaskan.. karena banyak sekali orangorang mengcopy paste video asli kemudian mengshare tidak sesuai dengan yang asli dengan akun. (Responden ke-4, Dl).

Melalui ungkapan tersebut, maka proses seleksi akun media sosial juga menjadi poin penting untuk mendapatkan pemahaman baru atau memperkuat pemahaman dalam pembelajaran agama. Hal ini mengacu pada ajaran yang disajikan. Sebagaimana salah satu responden mengungkapkan alasan mengapa mengakses akun media sosial sebagai salah satu sumber belajar agama sebagai berikut.

"Pada masa ini sosial media merupakan sarana utama untuk belajar agama, sangat membantu untuk menambah pengetahuan serta amalan-amalan baik lainnya". (Responden ke-14, Krw).

Berdasarkan ungkapan responden, maka dorongan mereka untuk mecari informasi keagamaan salah satunya melalui media sosial. Perubahan tren saat ini membentuk pola pembelajaran berbasis digital. Sebagaimana proses pembelajaran agama dapat menggunakan berbagai sumber informasi digital yang tersebar dalam ruang media sosial. Ketertarikan responden dalam menggunakan media sosial dapat dilihat melalui salah satu penjelasan informan sebagai berikut.

"Suguhan dakwah yang disampaikan melalui media sosial sangat menarik sekali, tampilan durasi yang relatif singkat dengan materi yang padat membuat saya menjadi paham akan hal yang berkaitan dengan agama walaupun hanya sedikit, tetapi sangat bermanfaat sekali. Saya suka menonton video yang bernuansa keagamaan untuk menambah pengetahuan keagamaan." (Responden ke-19, Mm).

Melalui pernyataan tersebut, maka fungsi media sosial menjadi kuat sebagai salah satu media yang dapat memberi informasi keagamaan. Sebagimana salah satu pernyataan informan yang mendukung sebagai berikut.

"Medsos sangat membantu sekali, terutama dalam belajar agama. Sekarang apapun agamanya bisa dipelajari melalui medsos. Bukan menepikan kitab suci, hadits atau apalah namanya, disini medsos perannya sebagai penunjang.

(Responden ke-2, Ad).

Meskipun sumber agama masih pada kitab suci masing-masing umat beragama, namun peran medsos masih sebatas media penunjang kebutuhan masyarakat. Hal ini menunjukkan bahwa situasi maupun kondisi yang membentuk pola pembelajaran berbasis digital. Selain itu, alasan para pengguna juga beragam, sebagaimana uraian informan berikut.

"Informasi yang ada di media sosial sangat membantu belajar agama. Namun, tak bisa dipungkiri sosok nyata seorang guru masih sangat dibutuhkan. Karena materi yang didapatkan melalui video youtube ataupun artikel, ada yang bisa dipahami da nada yang butuh penjelasan lebih lanjut. Dengan adanya sosok nyata seorang guru, ilmu yang kita dapatkan lebih luas, lebih dari sekedar yang di artikel atau yang tercantum dalam video, jika ragu bisa ditanyakan lebih lanjut. Tidak semua video di youtube full penjelasan, ada yang terpotong. Jadi lebih baik selain tatap muka." (Responden ke-3, Brp).

Melalui pernyataan responden, maka peranan guru, mentor atau pembimbing juga sangat penting. Hal ini menandakan bahwa kebutuhan media sosial hanya sebatas penunjang materi, tapi tidak ada interaksi dua arah, sehingga masih diperlukan akses tanya jawab bagi para pengguna media sosial untuk mengkonfirmasi maupun menanyakan halhal yang belum jelas dalam pemaparan materi yang disunguhkan melalui video maupun konten keagamaan di media sosial. Oleh sebab itu, kecenderungan generasi muda untuk mengakses media sosial dan peralihan sistem pembelajaran keagamaan dapat dilakukan melalui perantara media sosial yang beragam. 
Selain itu, salah satu alasan konkrit dalam pemilihan media sosial sebagai perantara belajar agama adalah desain visual yang menarik. Sebagaimana pernyataan responden berikut.

"Suguhan dakwah yang disampaikan melalui media sosial sangat menarik sekali, tampilan durasi yg relative singkat dengan materi yang padat membuat saya menjadi paham akan hal yang berkaitan dengan agama walaupun hanya sedikit, tetapi itu sangat bermanfaat sekali." (Responden ke19, $\mathrm{Mm}$ ).

Adapun tren pembelajaran agama di media sosial juga positif. Pemanfaatan media sosial tidak terbatas ruang dan waktu, siapapun bisa mengakses sesuai dengan kebutuhan konten yang diinginkan. Melalui perantara media sosial, maka salah satu responden dapat mengungkapkan bahwa:

"Media sosial dianggap memenuhi banyak kebutuhan masyarakat. Mulai dari kebutuhan komunikasi, interaksi bahkan belajar tentang keagamaan. Respon saya setelah belajar agama di medsos adalah sangat membantu memudahkan kita yang memiliki keterbatasan waktu untuk hadir di forum pengajian. (Responden ke-30, Sh).

Berpijak dari pernyataan responden, sistem digital memberikan nuansa positif bagi perkembangan strategi pembelajaran saat ini. Ketertarikan dan kecenderungan masyarakat terhadap adaptasi media sosial untuk membentuk aktivitas positif dalam rangka membangun pemahaman keagamaan melalui ragam platform yang tersedia.

Kebutuhan topik pembelajaran keagamaan juga menjadi salah satu daya tarik di media sosial. Sebagaimana dapat diuraikan melalui sebaran data berikut ini.

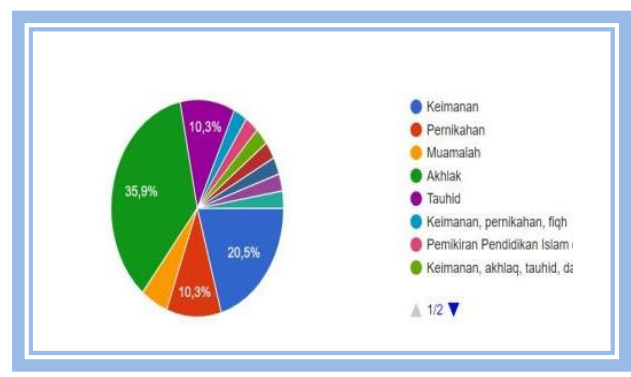

Gambar 6. Tema Pembelajaran
Berdasarkan gambar 6, maka topik paling menarik menunjukkan pada topik akhlak yakni sebanyak 35,9\%. Hal ini menjadi rujukan bahwa kebutuhan topik ini menjadi tren di kalangan masyarakat. Selanjutnya sebanyak 20,5\% cenderung pada topik keimanan. Selain itu, sebanyak 10,3\% cenderung pada topik pernikahan dan tauhid. Selebihnya tersebar pada topik lainnya seperti muamalah, motivasi dan pemikiran pendidikan.

Berdasarkan temuan tersebut, topik pembelajaran menjadi satu penilaian kebutuhan masa kini. Akhlak menjadi tren pertama yang memiliki dampak bagi kegiatan keseharian masyarakat. Sebagaimana salah satu ungkapan responden bahwa:

"Akhlak dasar ilmu untuk pondasi dalam mendalami bidang ilmu lainnya. Maka, penting sekali bagi saya untuk memahami apa itu akhlak dalam perspektif Islam. Pembahasan ini menarik sekali. (Responden ke-29, Wp).

Melalui sebaran topik ini, maka salah satu kecenderungan responden menunjukkan pemahaman mereka terkait tentang topik ini. Atas dasar itu, adanya platform media sosial dapat memfasilitasi kebutuhan mereka terhadap berbagai persoalan dalam kehidupan sehari-hari.

Adapun tingkat kepercayaan responden terhadap media sosial juga perlu digambarkan melalui sebaran data berikut.

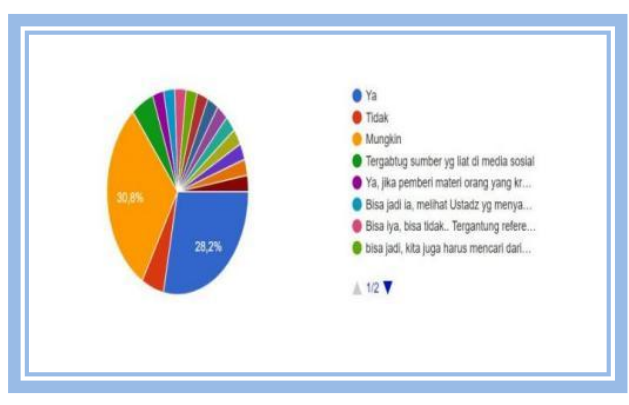

\section{Gambar 7. Tingkat Kepercayaan Responden}

Berdasarkan gambar 7 maka tingkat kepercayaan responden terhadap konten media sosial sebagai sumber pembelajaran agama yakni sebanyak $28,2 \%$ valid. Adapun sebanyak 30,8\% mengaku masih ragu-ragu. Sebagaimana salah satu 
informan mengungkapkan bahwa:

"Pada masa pandemi sosial media merupakan sarana utama belajar agama. Sangat membantu menambah ilmu pengetahuan serta amalan-amalan baik lainnya." (Responden ke-15, Ly).

"Tidak leluasa dalam bertanya yang belum dipahami, video terpotong dan tidak semua masalah yang ingin kita tanyakan ada videonya, belajar dari artikel juga agak sulit karena belum yakin kebenaran sumbernya." (Responden ke-23, Mr).

Berpijak dari beberapa pernyataan responden, maka masih terdapat berbagai masalah maupun kekurangan dalam menjadikan media sosial sebagai sumber belajar agama. Sebagaimana kurangnya kevalidan bagi konten yang diunggah dalam media sosial maupun keterbatasan interaksi antar pendakwah dan pendengar. Melalui keterbatasan ini, para pengguna media sosial tidak menjadikan sumber utama dalam menjawab problematika yang dimiliki, sebagaimana media sosial hanya sebagai penunjang. Akan tetapi, intensitas penggunaannya jauh lebih tinggi dibandingkan kajian tatap muka. Melalui sebaran data tersebut, maka media sosial masih menjadi alternatif untuk mencari sumber pembelajaran agama. Sehingga, masih diperlukan uji kelayakan konten yang disajikan dalam media sosial.

\section{Pembahasan}

Berpijak dari sumber temuan yang dihasilkan, maka media sosial masih menjadi satu alternatif sumber kegiatan keagamaan bagi masyarakat Indonesia. Sebagaimana peran media sosial dapat memberikan pengaruh positif bagi pemahaman keagamaan, seperti pemilihan konten yang menjadi kebutuhan masyarakat (Rafa' al \& S. Sangadji, 2020). Selain itu, media sosial juga menjadi satu pilihan masyarakat yang memandang kajian sumber keagamaan dapat diakses tidak terbatas ruang dan waktu (Aisa \& Lisvita, 2020).

Proses pemilihan platform terbanyak memberikan pilihan bagi masyarakat untuk memilih konten yang diinginkan. Sebagaimana YouTube mendapat posisi tertinggi dalam pemilihan platform online. Media YouTube dapat menyajikan model video maupun film yang menjadi sumber pembelajaran agama. Hal ini didukung oleh kecenderungan proses belajar masyarakat yang mengintegrasikan media audiovisual (Akmaliah, 2020).

Melalui berbagai platform media sosial, maka masyarakat dapat mengakses pembelajaran keagamaan mereka dengan asas fleksibilitas. Meskipun tidak ada kesempatan proses tanya jawab ataupun interaksi dua arah di YouTube, akan tetapi masyarakat mendapatkan informasi terkait kebutuhan tema agama yang mereka peroleh. Proses tanya jawabpun dapat dilakukan di platform media sosial lainnya. Atas dasar itu, kebutuhan informasi dan pemahaman keagamaan saat ini tidak terhalang oleh keterbatasan tempat dan waktu (Choliq, 2018).

Penyampaian sebuah gagasan atau informasi tidak lagi harus dilakukan dalam sebuah ruang publik, seperti di balai desa, auditorium, dengan mengundang sebanyakbanyak audience, semuanya sekarang bisa dilakukan di dunia maya (Cahyono, 2016). Untuk para konsumen atau pengguna internet situasi ini membuat mereka bisa leluasa menentukan pilihan materi dan narasumbernya. Tapi benarkah "dunia maya" dapat memberi jaminan dan akurasi terhadap kebenaran yang disampaikan. Banyak perdebatan tentang hal ini, bahkan tidak sedikit yang meragukan. Intinya, mengaji agama di internet berpotensi mengundang bahaya, terutama terhadap konten keagamaan dari mereka yang beridentitas anonim. Celakanya, tidak semua masyarakat punya kesempatan untuk memilah dan memilih konten dan sumber keagamaan yang ada di dunia maya. Akibatnya banyak dari masyarakat yang kerapkali menyimpang dari ilmu pengetuhan yang ia peroleh.

Sudah ada peralihan praktek keagamaan pada zaman ini, sebagaimana agama tidak lagi dipahami seperti dahulu, dimana ritual keagamaan adalah sesuatu yang tidak layak untuk dipertanyakan, dibantah, atau dijalankan di luar pakem. Namun kini, dalam kehidupan masyarakat industri dan modern, tuntutan masyarakat menghendaki 
pada hal-hal yang instan, praktis, dan cepat. Tak terkecuali dalam beragama (Taufik, 2020).

Menggunakan internet sebagai media dalam aktivitas dakwah bukanlah hal baru, namun internet juga telah membuka sejumlah kemungkinan baru bagi lahirnya gerakan-gerakan dan aktivisme dakwah. Internet dengan arena yang begitu luas dan memiliki jangkauan global tidak hanya dapat dipandang sebagai medium bagi aktivitas dakwah, misalnya dengan menyebarkan beragam informasi keislaman secara luas melalui website, blog, media sosial, atau paltform lainnya tetapi juga telah menjadi sebuah "lingkungan" baru yang signifikan, dimana umat Islam dapat membentuk identitas dirinya sendiri.

Kebutuhan platform media sosial juga perlu didukung manajemen yang baik, seperti penyajian konten maupun peningkatan minat terhadap platform yang diinginkan (Faisal, 2020). Sajian konten di ruang digital membantu para pengguna menemukan pemecahan problematika kebutuhan keagamaan mereka (Hefni, 2020). Internalisasi konten positif juga ditingkatkan melalui penyebaran akun dan platform media sosial sehingga menghasilkan kebermanfaatan positif bagi masyarakat luas.

Melalui berbagai platform media sosial, maka masyarakat dapat mengakses pembelajaran keagamaan mereka dengan asas fleksibilitas. Meskipun tidak ada kesempatan proses tanya jawab ataupun interaksi dua arah, masyarakat mendapatkan informasi terkait kebutuhan tema agama yang mereka peroleh. Atas dasar itu, kebutuhan informasi dan pemahaman keagamaan saat ini tidak terhalang oleh keterbatasan tempat dan waktu.

Kebutuhan platform media sosial juga perlu didukung manajemen yang baik, seperti penyajian konten maupun peningkatan minat terhadap platform yang diinginkan (Faisal, 2020). Sajian konten di ruang digital membantu para pengguna menemukan pemecahan problematika kebutuhan keagamaan mereka (Hefni, 2020). Selain itu, ruang digital dapat meningkatkan percepatan bagi sumber- sumber konten keagamaan (Muhtador, 2018; Kurnia \& Fitriyani, 2018). Akan tetapi, masih ada keterbatasan yang menjadi kekurangan media sosial sebagai sumber keagamaan, seperti kurangnya daya psikologis antar komunikator yaitu pengguna media dan penyebar konten (Killian, 2014). Hal ini menguatkan bahwa proses interaksi dua arah masih diperlukan sebagai bentuk dorongan pemahaman bagi para pengguna media sosial, sehingga dalam proses pemahaman lebih terarah dan sesuai dengan tujuan yang diinginkan.

Melalui pemanfaatan teknologi dalam desain platform media sosial, proses internalisasi konten juga dipertimbangkan, sebagaimana adanya daya dukung atau karisma dari para ustadz yang memberikan ceramah online (Qudsy, 2018). Hal ini menuntut para pengguna untuk selektif dalam mencari konten keagamaan (Gumilar et al., 2017; Nuryana, 2019; Sari, 2017; Zaduqisti et al., 2020). Internalisasi konten positif juga ditingkatkan melalui penyebaran akun dan platform media sosial sehingga menghasilkan kebermanfaatan positif bagi masyarakat (Faiqah et al., 2018). Maka, perlu adanya pengawasan dari para pemangku kebijakan terhadap konten yang disunguhkan dalam unggahan akun di media sosial.

Pada dasarnya, pengembangan media online memberikan tuntutan kreativitas bagi penyebar akun dakwah maupun para pengguna media sosial (Azizah, 2019; Wulandari, 2018). Kreativitas yang dimunculkan berupa desain visual dan kebutuhan konten di masyarakat (Eide, 2020). Inovasi yang dikembangkan juga berupa proses diskusi menarik maupun desain blogging (Kurdi, 2020). Selain itu, kreativitas tersebut dituangkan dalma bentuk animasi, gambar, video maupun desai lainnya. Sehingga keberagaman desain menjadi pilihan bagi para pengguna media sosial(Nuri, 2017). Hal ini menjadi poin penting bagi keberhasilan media sosial sebagai sumber belajar penunjang dalam keagamaan. Kebutuhan ini tidak dapat dipisahkan dalam zaman sekarang, dimana proses interaksi di media sosial sangat tinggi. Melalui adanya komunitas keagamaan, maka akan terbentuk bahasa keagamaan yang timbul dari adanya 
komunikasi di media sosial (Fakhruroji et al., 2020).

Pembelajaran agama di media sosial juga memberikan pola pembelajaran informal yang relevan dengan kebutuhan masyarakat dunia (Benková, 2019). Kebutuhan ini berdasar pada keterbatasan interaksi pada ruang dan waktu yang sempit, sehingga penelusuran konten dan kajian dapat ditelusuri dalam platform media sosial. Terutama pada golongan muda yang paling intens dalam menggunakan platform ini (Diniaty \& Vebrianto, 2020). Efisiensi dan efektivitas media sosial juga menjadi pengaruh bagi pengguna untuk memanfaatkan platform media sosial (Mathew et al., 2019). Terutama selektif dari ujaran kebencian dan hal-hal negatif dari dampak penggunaan media sosial sebagai sumber belajar agama (Kursuncu et al., 2019 ; Miller, 2017; Yar, 2018). Proses selektif ini berfungsi menelusuri konten yang valid, sebagaimana ditemukan berbagai pelanggaran kasus terhadap ketidakabsahan konten keagamaan (Myers, 2018). Temuan penelitian lain juga mengkonfirmasi bahwa berbagi isi pengalaman media sosial memiliki hubungan yang signifikan dan positif tentang niat perilaku positif pengguna akun dakwah (Muslim et al., 2020). Mereka yang menggunakan media sosial untuk belajar agama lebih banyak dan berharap untuk dengan cepat memenuhi kebutuhan informasi mereka (Dinham \& Shaw, 2017; Ratcliff et al., 2017). Selain itu, media sosial juga membentuk komunitas keagamaan yang beragam (Baker-Smemoe \& Bowie, 2015;. Ferguson et al., 2021; Kursuncu et al., 2019).

Meskipun tren belajar agama kini telah beralih pada sistem online, para pengguna platform juga menyeleksi berbagai konten yang menjadi kebutuhan mereka. Sebagaimana mereka menyeleksi berbagai platform ataupun akun yang dijadikan sumber belajar. Hal ini mengindikasikan bahwa kepercayaan mereka tidak sepenuhnya terhadap konten-konten yang tersedia. Sebagaimana salah satu unsur yang menjadi pertimbangan adalah tema yang menarik dalam menggali sumber informasi teraktual (Arenggoasih \& Wijayanti, 2020; Kurdi, 2018). Selain itu, adanya dukungan berbagai kelompok keberagamaan yang membangun platform dalam rangka penyebaran konten keagamaan (Salik, 2019; Syahputra, 2020). Melalui dialog secara online, maka proses interaksi belajar agama di jejaring sosial menjadi opsi bagi masyarakat pada umumnya (Rohman, 2020; Sudarji, 2020).

Adapun dukungan dari berbagai platform yang bervariasi seperti dari kalangan santri milenial, maupun instansi pemerintahan dapat mendorong tingkat kepercayaan masyarakat dalam mengakses sumber belajar agama melalui media online (Mujahidin \& Martanegara, 2020). Sebagaimana temuan mengungkapkan bahwa materi yang dipilih disesuaikan dengan tingkat usia, misalnya pada generasi muda lebih mendorong tema yang berkaitan tentang moderasi beragama (Rafa' al \& S. Sangadji, 2020). Dengan adanya peran masyarakat juga mendorong keberhasilan sumber belajar agama berbasis online tanpa melupakan esensi dalam mengambil sumber belajar agama.

Berpijak dari beberapa ulasan sebelumnya, para pengguna media sosial juga patut untuk menyeleksi dengan bijak tanpa menyudutkan pihak-pihak lainnya. Hal ini disebabkan oleh dampak penggunaan media sosial yang kurang bijak seperti doktrin agama yang tidak sesuai dengan sumber agama yang asli seperti AlQur' an dan Sunnah (Kosasih, 2019). Sehingga, adanya seleksi dan pemantauan dapat memberikan kepuasan sumber keberagamaan melalui substansi yang benar sesuai dengan kebutuhan (Purwanto \& Fauzi, 2019; Wibisono, 2020).

\section{PENUTUP}

\section{Simpulan}

Berdasarkan hasil temuan penelitian, maka tren pembelajaran keagamaan menggunakan media sosial yang paling tinggi menggunakan platform YouTube. Hal itu mengindikasikan bahwa kebutuhan konten keagamaan berbasis media audiovisual mampu memberikan pemahaman dan ketertarikan minat pengguna media sosial. Adapun tema yang paling dibutuhkan terkait tentang akhlak. 
Penelitian ini menemukan bahwa tren pengguna media sosial dalam rangka menelaah dan memahami informasi keagamaan di masa kini menjadi satu kebutuhan yang mutlak, meskipun tidak ada interaksi dua arah. Berbagai keterbatasan media sosial seperti kevalidan konten juga masih menjadi pertimbangan yang penting bagi penguatan sumber belajar agama. Sehingga media sosial hanya menjadi salah satu alternatif pembelajaran keagamaan di era digital tanpa dibatasi akses ruang dan waktu bagi para penggunanya.

\section{Rekomendasi}

Berbagai keterbatasan media sosial sebagai bahan referensi maupun media penunjang belajar agama, masih terdapat berbagai kekurangan yang perlu diselesaikan, seperti kebutuhan platform media sosial dua arah untuk ajang diskusi bagi para pengguna dan pendakwah. Selain itu, perlunya peran penting dari para pemegang kebijakan di Pendidikan Islam Kementerian Agama untuk mengontrol situs media sosial yang tidak relevan bagi ajaran keagamaan serta membatasi situs Web yang buruk dapat diunggah melalui media sosial. Sebagaimana media sosial menjadi satu perantara bagi kesejahteraan umat dalam mendapatkan sumber-sumber keagamaan yang relevan dengan kebutuhannya. Adapun kekurangan penelitian ini masih terbatas pada variabel dan topik yang sempit, yaitu tren belajar agama di media sosial. Sehingga, penelitian ini merekomendasikan penelitian lanjutan bagi masyarakat umum maupun para pemangku kebijakan di Pendidikan Islam Kementerian Agama untuk menganalisis topik pembahasan serta variasi sampel dan metode penelitian yang beragam. Sehingga, penelitian dapat berlanjut untuk menguji efektivitas masing-masing media sosial seperti YouTube, Instagram, Facebook maupun aplikasi lainnya dalam menunjang proses pemahaman ajaran keagamaan pada masyarakat Indonesia. Sehingga media sosial dapat memberikan kontribusi positif bagi pemahaman masyarakat terhadap ajaran keagamaan yang benar. 


\section{DAFTAR PUSTAKA}

Abdullah, H., Zaini, A. R., Ab Latif, K. A., Ihsan, H., Ku Azizan, K. F., Wan Ngah, W. S., \& Mansor, N. (2018). Pendidikan Abad Ke - 21 Dalam Pengajaran Bahasa Arab Di Sekolah Menengah Di Malaysia: Amalan Dan Cabaran. 5th International Research Management \& Innovation Conference (5th IRMIC 2018).

Aisa, A., \& Lisvita, L. (2020). Penggunaan Teknologi Informasi dalam Pembelajaran Online Masa Covid-19. JoEMS (Journal of Education and Management ....

Akmaliah, W. (2020). The demise of moderate Islam: New media, contestation, and reclaiming religious authorities. Indonesian Journal of Islam and Muslim Societies, 10(1), 1-24. Diambil kembali dari: https://doi.org/10.18326/ijims.v10i1.1-24

Alika, R. (2019). Menag Sebut Belajar Agama Lewat Medsos Rawan Jadi Intoleran. Diambil kembali dari :

https://www.bing.com/search?q=Fachrul+dalam+Rapat+Koordinasi+Nasional+Indonesia+Maju +di+Sentul+International+Convention+Center\%2C+Bogor\%2C+Rabu+(13\%2F11)\&cvid=1871 c433a6484aff86482b858614b0ea\&aqs=edge..69i57.1524j0j1\&pglt=43\&FORM=ANNTA1\&PC $=$ LCTS

Arenggoasih, R. R. W., \& Wijayanti, C. R. (2020). Pesan Kementerian Agama dalam Moderasi Melalui Media Sosial Instagram. Jurnal Jurusan Jurnalistik, 06, 160-176.

Azizah, N. A. (2019). Pengembangan Aplikasi "Smart Tajwid" Berbasis Android untuk Meningkatkan Motivasi Belajar Tajwid Siswa pada Mata Pelajaran Pendidikan Agama Islam. EDULAB: Majalah Ilmiah Laboratorium Pendidikan, 4(1), 47-70. Diambil kembali dari : https://doi.org/10.14421/edulab.2019.41-04

B.Miles, M., \& Huberman, M. (1992). Analisis Data Kualitatif. UI Press.

Baker-Smemoe, W., \& Bowie, D. (2015). Linguistic behavior and religious activity. Language and Communication, 42, 116-124. Diambil kembali dari : https://doi.org/10.1016/j.langcom.2014.12.004

Benková, Z. (2019). Media education and religion in Slovak republic. European Journal of Science and Theology, 15(2), 159-170.

Cahyono, A. S. (2016). Pengaruh media sosial terhadap perubahan sosial masyarakat di Indonesia. Jurnal Ilmu Sosial \& Ilmu Politik Diterbitkan Oleh Fakultas Ilmu Sosial \& Politik, Universitas Tulungagung, 9(1), 140-157. Diambil kembali dari :

http://www.jurnal-unita.org/index.php/publiciana/article/download/79/73

Choliq, A. (2018). Dakwah melalui Media Sosial Facebook. Jurnal Dakwah Tabligh, 16(2), 170-187.

Dinham, A., \& Shaw, M. (2017). Religious literacy through religious education: The future of teaching and learning about religion and belief. Religions, 8(7). Diambil kembali dari : https://doi.org/10.3390/rel8070119

Diniaty, A., \& Vebrianto, R. (2020). The Millenial Muslim Activity using Internet: An Indonesian Perception. Journal of Cognitive Sciences and Human Developmen, 6(2), 16-26. 
Eide, M. (2020). Religion in Children's Visual Media: A Qualitative Content Analysis of Preschool Holiday Specials. Journal of Media and Religion, 19(3), 108-126. Diambil kembali dari : https://doi.org/10.1080/15348423.2020.1812339

Faiqah, N., Pransiska, T., Sunan, U. I. N., \& Yogyakarta, K. (2018). Radikalisme Islam VS Moderasi Islam: Upaya Membangun Wajah Islam Indonesia yang Damai. Al-Fikra: Jurnal Ilmiah Keislaman, 17(1), 33-60.

Faisal, M. (2020). Manajemen Pendidikan Moderasi Beragama Di Era Digital. Journal of International Conference On Religion, Humanity and Development Title, 195-202.

Fakhruroji, M., Rustandi, R., \& Busro, B. (2020). Bahasa Agama di Media Sosial: Analisis Framing pada Media Sosial "Islam Populer." Jurnal Bimas Islam, 13(2), 203-234. Diambil kembali dari : https://doi.org/10.37302/jbi.v13i2.294

Ferguson, J., Ecklund, E. H., \& Rothschild, C. (2021). Navigating religion online: Jewish and muslim responses to social media. Religions, 12(4), 12. Diambil kembali dari : https://doi.org/10.3390/rel12040258

Gumilar, G., Adiprasetio, J., \& Maharani, N. (2017). Literasi media: cerdas menggunakan media sosial dalam menanggulangi berita palsu. Jurnal Pengabdian Kepada Masyarakat, 1(1), 35-40.

Hatta, M. (2018). Media Sosial sebagai Sumber keberagamaan Alternatif Remaja. Dakwah: Jurnal Kajian Dakwah Dan Kemasyarakatan, 22(1), 1-30.

Hefni, W. (2020). Moderasi Beragama dalam Ruang Digital: Studi Pengarusutamaan Moderasi Beragama di Perguruan Tinggi Keagamaan Islam Negeri. Jurnal Bimas Islam, 13(1), 1-22. Diambil kembali dari : https://doi.org/10.37302/jbi.v13i1.182

Islam, M. T. (2019). The Impact of Social Media on Muslim Society: From Islamic Perspective. International Journal of Scientific \& Technology Research, 3(3), 95-441. Diambil kembali dari : https://www.entrepreneur.com/article/297990

Kemp, S. (2021). Digital 2021: The Latest Insights Into The States of Digital. Diambil kembali dari : https://wearesocial.com/blog/2021/01/digital-2021-the-latest-insights-into-the-state-of-digital

Khosyatillah, A. (2018). Dampak Media Sosial Terhadap Perilaku Keagamaan (Studi Kasus 7 Mahasiswa Jurusan Studi Agama Fakultas Ushuluddin dan Filsafat Universitas Islam Negeri Sunan Ampel Surabaya). 1.

Killian, N. (2014). Peran Teknologi Informasi Dalam Komunikasi Antar Budaya Dan Agama. Jurnal Dakwah Tabligh, 15(2), 159-176.

Kosasih, E. (2019). Literasi Media Sosial dalam Pemasyarakatan Sikap Moderasi Beragama. Jurnal Bimas Islam, 12(2), 263-296. Diambil kembali dari : https://doi.org/10.37302/jbi.v12i2.118

Kurdi, M. S. (2018). Madrasah Ibtidaiyah dalam Pandangan Dunia: Isu-Isu Kontemporer dan Tren dalam Pendidikan. Al Ibtida: Jurnal Pendidikan Guru MI, 5(2), 231. Diambil kembali dari : https://doi.org/10.24235/al.ibtida.snj.v5i2.3194

Kurdi, M. S. (2020). Doktrin Ajaran Islam untuk Generasi Muslim Di Masa Pandemi Info Artikel Keyword Abstrak. Jurnal Hawa, 2(2), 159-175.

Kurnia, A., \& Fitriyani, N. (2018). Pemanfaatan Teknologi Dalam Proses Pembelajaran Pai Di Universitas Mataram. Prosiding Seminar Nasional II APPPI NTB 2018, June 2020. 
Kursuncu, U., Gaur, M., Castillo, C., Alambo, A., Thirunarayan, K., Shalin, V., Achilov, D., Arpinar, I. B., \& Sheth, A. (2019). Modeling islamist extremist communications on social media using contextual dimensions: Religion, ideology, and hate. Proceedings of the ACM on HumanComputer Interaction, 3(CSCW). Diambil kembali dari : https://doi.org/10.1145/3359253

Lexy J Moleong. (2007). Metodologi Peneleitian Kualitatif. Rosdakarya Offset.

Mathew, B., Dutt, R., Goyal, P., \& Mukherjee, A. (2019). Spread of Hate Speech in Online Social Media. WebSci 2019 - Proceedings of the 11th ACM Conference on Web Science, 173-182. Diambil kembali dari : https://doi.org/10.1145/3292522.3326034

Miller, C. (2017). Australia's anti-Islam right in their own words. Text as data analysis of social media content. Australian Journal of Political Science, 52(3), 383-401. Diambil kembali dari : https://doi.org/10.1080/10361146.2017.1324561

Muh Muhtador. (2018). Studi Kritis atas Transmisi dan Otoritas Keagamaan di Media Sosial. Fikrah, 6(2), 323-340.

Mujahidin, E., \& Martanegara, I. H. (2020). Tren penelitian pendidikan sains-agama Indonesia. Ta'dibuna: Jurnal Pendidikan Islam, 9(2), 301. Diambil kembali dari : https://doi.org/10.32832/tadibuna.v9i2.3558

Muslim, A., Harun, A., Ismael, D., \& Othman, B. (2020). Social media experience, attitude and behavioral intention towards umrah package among generation $\mathrm{X}$ and Y. Management Science Letters, 10(1), 1-12. Diambil kembali dari : https://doi.org/10.5267/j.msl.2019.8.020

Myers West, S. (2018). Censored, suspended, shadowbanned: User interpretations of content moderation on social media platforms. New Media and Society, 20(11), 4366-4383. Diambil kembali dari : https://doi.org/10.1177/1461444818773059

Nasrullah, R. (2015). Media Sosial: Perspektif Komunikasi, Budaya, dan Sosioteknologi. In Simbiosa Rekatama Media.

Nuri, S. (2017). Belajar Islam di Media Sosial. Buletin KPIN, 3(10), 1-4.

Nuryana, Z. (2019). Pemanfaatan Teknologi Informasi Dalam Pendidikan Agama Islam. Tamaddun, 19(1), 75. Diambil kembali dari : https://doi.org/10.30587/tamaddun.v0i0.818

Purwanto, Y., \& Fauzi, R. (2019). Internalisasi Nilai Moderasi Melalui Pendidikan Agama Islam di Perguruan Tinggi Umum. EDUKASI: Jurnal Penelitian Pendidikan Agama Dan Keagamaan, 17(2), 110-124. Diambil kembali dari : http://jurnaledukasikemenag.org

Qudsy, S. Z. (2018). Pesantren Online: Pergeseran Otoritas Keagamaan di Dunia Maya. Living Islam: Journal of Islamic Discourses, II(2), 169-187.

Rafa'al, M., \& S. Sangadji, S. (2020). Merawat Moderasi Beragama Cerdas Bermedia di Pondok Pesantren Harisul Khairaat Kelurahan Ome Kota Tidore Kepulauan. Jurnal Abdimas Bina Bangsa, 1(2), 223-230. Diambil kembali dari : https://doi.org/10.46306/jabb.v1i2.34

Ramadhan, R., \& Destiana, H. (2019). Pengaruh Media Sosial Youtube terhadap Perkembangan Dakwah Islam dengan Metode Structural Equation Modeling ( SEM ). Jurnal \& Penelitian Teknik Informatika, 1(No. 3 Oktober 2018), 61.

Ratcliff, A. J., McCarty, J., \& Ritter, M. (2017). Religion and New Media: A Uses and Gratifications Approach. Journal of Media and Religion, 16(1), 15-26. Diambil kembali dari : https://doi.org/10.1080/15348423.2017.1274589 
Rohman, D. A. (2020). Peran Media Cetak dalam Narasi Moderasi Islam Indonesia. Anida (Aktualisasi Nuansa Ilmu Dakwah), 20(1), 23-45. Diambil kembali dari :https://doi.org/https://doi.org/10.15575/anida.v20i1.8868

Salik, M. (2019). Conserving moderate Islam in Indonesia: An analysis of Muwafiq's speech on online media. Journal of Indonesian Islam, 13(2), 373-394. Diambil kembali dari :https://doi.org/10.15642/JIIS.2019.13.2.373-394

Sari, P. (2017). Fenomena Penggunaan Media Sosial Instagram Sebagai Komunikasi Pembelajaran Agama Islam Oleh Mahasiswa Fisip Universitas Riau. Fenomena Penggunan Media Sosial Instagram Sebagai Komunikasi Pembelajaran Agama Islam Oleh Mahasiswa Fisip Universitas Riau, 53(9), 1-13.

Sofiuddin. (2018). Transformasi Pendidikan Islam moderat dalam Dinamika Keutamaan dan Kebangsaan. Jurnal Dinamika Penelitian: Media Komunikasi Sosial Keagamaan, 18(2), 347366.

Sudarji. (2020). Moderasi Islam: Untuk Peradaban dan Kemanusiaan. Jurnal Edukasia: Jurnal Pendidikan Dan Pembelajran, 1(1), 97-109.

Syahputra, M. C. (2020). Jihad Santri Millennial Melawan Radikalisme di Era Digital: Studi Gerakan Arus Informasi Santri Nusantara di Media Sosial. Jurnal Islam Nusantara, 4(1), 69-80. Diambil kembali dari : https://doi.org/10.33852/jurnalin.v4i1.187

Taufik, A. (2020). Strategi Pembelajaran Bahasa Arab Berbasis Internet. SELL Journal, 5(1), 55.

Wibisono, Y. (2020). Revitalisasi Peran Strategis Penghulu Dalam Pelayan- An Kegamaan Masyarakat Dan Pengarusutamaan Mod- Erasi Beragama. Al-Mabsut: Jurnal Studi Islam Dan Sosial, 14(1), 193-205.

Wibowo, A. (2019). Penggunaan Media Sosial sebagai Trend Media Dakwah Pendidikan Islam di Era Digital. Jurnal Islam Nusantara, 03(02), 339-356.

Wulandari, N. (2018). Pemamfaatam Social Facebook sebagai Media Belajar Pendidikan Agama untuk Meningkatkan Motivasi dan Hasil Belajar Siswa. Tarbiyatuna, 3(1), 82-106.

Yar, M. (2018). A Failure to Regulate? The Demands and Dilemmas of Tackling Illegal Content and Behaviour on Social Media. International Journal of Cybersecurity Intelligence and Cybercrime, $1(1), \quad 5-20 . \quad$ Diambil kembali dari : http://vc.bridgew.edu/ijcichttp://vc.bridgew.edu/ijcic/vol1/iss1/3

Yusnawati, Wira, A., \& Afriwardi. (2021). Internalisasi Nilai-Nilai Moderasi Beragama di Instagram. Tatar Pasundan, 15(1), 1-9.

Zaduqisti, E., Mashuri, A., Zuhri, A., Haryati, T. A., \& Ula, M. (2020). On being moderate and peaceful: Why Islamic political moderateness promotes outgroup tolerance and reconciliation. Archive for the Psychology of Religion, 42(3), 359-378. Diambil kembali dari : https://doi.org/10.1177/0084672420931204

Zazin, N., \& Zaim, M. (2017). Media Pembelajaran Agama Islam Berbasis Media Sosial pada Generasi-Z. Proceeding Antasari International Conference. 